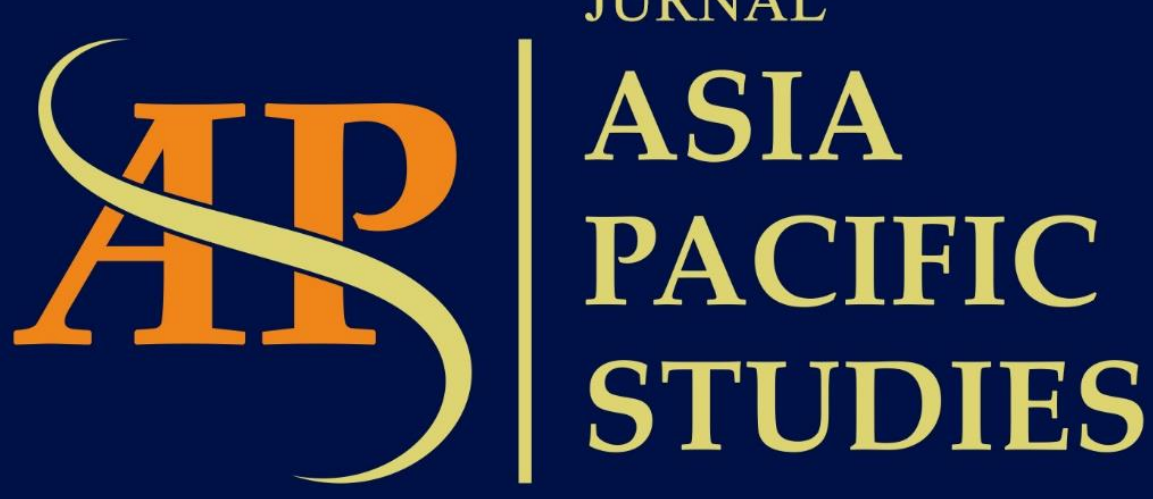

Journal of International Relations Study Program Faculty of Social and Political Sciences Universitas Kristen Indonesia

Volume I | Number 1 | January- June 2017 


\title{
THE CRISIS OF INTERNATIONAL LAW IN INTERNATIONAL POLITICAL ECONOMY: CASE STUDY OF SOUTH CHINA SEA DISPUTE
}

\author{
Obsatar Sinaga $^{1}$ dan Verdinand Robertua ${ }^{2}$ \\ ${ }^{1}$ International Relations Department, Universitas Padjajaran, J1 Raya Bandung Sumedang 21, Jatinangor, \\ Kabupaten Sumedang, Jawa Barat, 45363 \\ ${ }^{2}$ International Relations Department, Universitas Kristen Indonesia, Jl. Mayjen Sutoyo 2, Cawang, Jakarta 13630 \\ ${ }^{1}$ profesorobi@gmail.com, ${ }^{2}$ verdinand.robertua@gmail.com
}

\begin{abstract}
This research discussed the impact of Permanent Court of Arbitration's decision on the dynamic of South China Sea dispute. Court's decision in July 2016 to give South China Sea based on UNCLOS's regulation has provoked China's objection. This research question is on How to understand the crisis of international law in the international political economy using English School Theory in the case of South China Sea dispute? To answer the research question, this research is using English School Theory (ES) with its two pillars namely pluralism and solidarism. This research shows two findings. First, the PCA decision has been used by the Philippines to be bargaining tool to obtain economic cooperation and appeased the failure of PCA ruling. Secondly, the PCA decision has provided momentum for China to transform their policy related to the South China Sea dispute with its role as the great power. Thirdly, the structure of international law as the primary institution would be consists of great power politics, ASEAN and economic diplomacy.
\end{abstract}

Key words: South China Sea, English School, Permanent Court of Arbitration, international political economy, international law

\begin{abstract}
Abstrak
Penelitian ini membahas dampak keputusan Pengadilan Arbitrase mengenai sengketa Laut Cina Selatan. Keputusan pengadilan pada bulan Juli 2016 untuk memberi Laut Tiongkok Selatan berdasarkan peraturan UNCLOS telah memancing keberatan Tiongkok. Pertanyaan penelitian ini adalah bagaimana memahami krisis hukum internasional dalam ekonomi politik internasional dengan menggunakan Teori English School dalam kasus perselisihan Laut Tiongkok Selatan? Untuk menjawab pertanyaan penelitian, penelitian ini menggunakan Teori English School (ES) dengan dua pilarnya yaitu pluralisme dan solidarisme. Penelitian ini menunjukkan tiga temuan. Pertama, keputusan PCA telah digunakan oleh Filipina untuk menjadi alat tawar menawar untuk mendapatkan bantuan ekonomi dari China dan meredakan ketegangan akibat keputusan PCA. Kedua, keputusan PCA telah memberi momentum bagi Tiongkok untuk mengubah kebijakan mereka terkait dengan perselisihan Laut Cina Selatan dengan memainkan perannya sebagai negara adikuasa. Ketiga, struktur hukum internasional sebagai institusi primer terdiri atas politik negara adikuasa, ASEAN dan diplomasi ekonomi.
\end{abstract}

Kata Kunci: Laut Tiongkok Selatan, English School, Permanent Court of Arbitration, Ekonomi Politik Internasional, hukum internasional 


\section{Introduction}

The South China Sea is a semi-enclosed sea of 1.4 million square miles, bordered by 6 nations (China, Malaysia, Brunei Darussalam, Vietnam, the Philippines, Taiwan) that contain approximately 2 billion people. About a third of the world's shipping goes through its waters, which also provide vast amounts of food and whose seabed is rich in oil and gas (Hayton 2014, 6-7). South China Sea fall into two main groupings, the Paracel Islands in the northern part of the sea, and the Spratly Islands in the southern part. China, Taiwan, the Philippines, Vietnam, Brunei Darussalam, and Malaysia claim sovereignty over some of these land features and waters of South China Sea. China, through its "nine-dash line" map, has claimed at the whole area of the South China Sea. The other five stakeholders have protested to China over their claim that nine-dash lines has taken their territorial maritime sovereignty as granted by UNCLOS.

UNCLOS granted each nation exclusive economic zone with 200 miles from coastlines. Obviously nine-dash lines has violated the UNCLOS regime. On January 22, 2013, the Philippines filed a case to Permanent Court of Arbitration to claim the sovereignty of 200 miles of the Philippines' Exclusive Economic Zone and to sue the legal standing of the China's nine dashed lines.

China rejected to participate in the hearings and claimed that the case is illegal due to the absent of Chinese participation. On October 29, 2015, the PCA issued its ruling on "jurisdiction." The court concluded that it indeed had jurisdiction over the Philippines' case. On July 12, 2016 PCA stipulated that there was no legal basis for China to claim historic rights to resources within the sea areas falling within the 'nine-dash line' (Thanh-Dam Truong and Knio 2016, 223). The court found that China had violated the Philippines' sovereign rights in its exclusive economic zone by interfering with Philippine fishing and petroleum exploration, constructing artificial islands and failing to prevent Chinese fishermen from fishing in the zone.

The PCA also considered the effect on the marine environment of China's recent large-scale land reclamation and construction of artificial islands at seven features in the Spratly Islands and found that China had caused severe harm to the coral reef environment and violated its obligation to preserve and protect fragile ecosystems and the habitat of depleted, threatened, or endangered species. The PCA also found that Chinese authorities were aware that Chinese fishermen have harvested endangered sea turtles, coral, and giant clams on a substantial scale in the South China Sea and had not fulfilled their obligations to stop such activities.

Interestingly newly-elected the Philippines President Rodrigo Duterte didn't want to enforce the ruling. Instead, Duterte stated that the ruling possibly brought chaos to the region. The role of international law as solution for conflict became vague. The discourse of economic cooperation is more prominent that the enforcement of ruling as the long-term solution. Avoiding the discourse of the implementation of the ruling for the sake of stability and economic cooperation is like a time-bomb. We will deal with this issue again.

International Political Economy (IPE), a sub-discipline of International Relations, has provided bigger role for international law in settling disputes regarding international trade in World Trade Organization or the legitimacy of civil society in international organizations such as the European Union. South China Sea dispute become a test of the sustainability of international law as the primary institution of IPE. Early IPE thinkers such as Robert Gilpin, Friedrich List and Alexander Hamilton emphasized the primacy of state and its national interest as the universal norms of IPE. They believed that the anarchic situation of international affairs created anxiety and competition among the states and the power property is the solution of the conflict. However, the success of European integration within the European Union as the institutional framework has revolutionized the IPE and opened the studies of regionalism, international law and non-traditional issues in IPE. 
This research will use English School as the theoretical framework to look on the primary institution and secondary institution or the normative debate such as the sovereignty versus international law. The article wanted to understand the crisis of international law in the IPE using English School Theory in the case of South China Sea dispute.

\section{English School}

The legitimacy of international law is hotly debated in International Political Economy (IPE). Classic IPE thinkers rarely looked at international law in their theory-making process meanwhile new generation of IPE thinkers started to build IPE theories suitable to explain the role of international court such as International Court of Justice and World Trade Organization Dispute Settlement Body.

English School theory (ES) is IPE theory widely acknowledged by its contribution in globalization and international law studies. ES is deeply involved in a debate whether states must comply the international court decisions and whether the pursuit of national interest is handed over to the judgment of the international court. English School Theory, pioneered by Martin Wight, Hedley Bull and Barry Buzan, answered this debate by splitting up the theory into two division, the pluralism and the solidarism.

The English School dichotomy of pluralism and solidarism was inspired by debate between Lawrence Oppenheim and Hugo Grotius. The central difference between solidarism of Grotius and pluralism of Oppenheim is, according to the solidarism, there is solidarity or potential solidarity in international society sufficient to enable enforcement of the law against the lawbreakers, according to the latter, 'states do not exhibit solidarity of this kind, but are capable of agreeing only for certain minimum purposes which fall short of that of the enforcement of the law' (Bull, 1966, 52). So, in essence, what distinguishes the two positions is the difference in their respective empirical judgements about the world as it currently is, solidarism suggesting that there is much solidarity in the world already, and pluralism offering a more skeptical interpretation.

English School is known for its international society as the middle way or via media. Hedley Bull firstly introduced the trichotomy of international system, international society and world society in his books "Anarchical Society". The purpose of this trichotomy is to highlight the international society as the fora for unknown and overlapping units, functions and issues. The philosophical basis for international society is the inability of the Realism and Liberalism to grasp the complexity and paradox of contemporary IPE issues. The emergence of new actors such as academician, civil society and multinational corporation as well as the success of regional integration in the European Union can't be nicely put in Realism or Liberalism and thus needs a new theory. International society of English School then became relevant in looking the complexity of many IPE issues.

Bull defined international system as system that "is formed when two or more states have sufficient contact between them, and have sufficient impact on one's another decisions, to cause them to behave" (Bull 1977, 9). International society is defined as "a group of states, conscious of certain common interests and common values, form a society in the sense that they conceive themselves to be bound by a common set of rules in their relations with one another, and share in the working of common institutions" (Bull 1977, 13). The last part of trichotomy is world society that "takes individuals, non-state organizations and ultimately the global population as a whole as the focus of global societies identities and arrangements, and put transcendence of the states-system at the center of IR theory" (Buzan 2004, 7). These three different definition reflected the position Realism, Liberalism and English School in which English School emphasized the middle way of international society. 
The last characteristic of English School is the presence of primary institution and secondary institution. International law is considered as the primary institution of English School but the question is that there are some primary institution that are inherently contradicting each other. For example, in the case of climate change and global warming, there is contradicting primary institution between sovereignty and climate responsibility. In the case of prisoner torture, there is a conflict between sovereignty and human rights. Barry Buzan has developed a comprehensive view on the list of primary institutions namely sovereignty, territoriality, diplomacy, great power management, equality of people, market, nationalism, and environmental stewardship. Meanwhile Hedley Bull developed his primary institutions of balance of power, diplomacy, great power management, war, and international law. Barry Buzan urged the reader to develop the secondary institution elaborating the specifics and the components of each primary institutions. This gives greater opportunities for readers to creatively develop their own primary and secondary institutions. This article argues that international law is one of IPE's primary institution and it is the task of this article to elaborate the secondary institution of international law.

\section{International Political Economy (IPE)}

As a sub-discipline of International Relations, IPE is closely related to Robert Gilpin, the US scholar who campaign for specialization of IR in economy and globalization issues. Global Political Economy is considered as the key text for IPE and has spurred the growth of IPE books and scholars such as Theodore Cohn or Robert Falkner. Gilpin was curious on the lack of IR theoretical discourse on economic globalization and many IPE issues such as global economic crisis, oil embargo or trade wars. He said that economists have overemphasized the role of the corporation and trade dimension and neglected the role of states and political dimension in the context of economic globalization.

He introduced his perspective of state-centric realism that emphasized the anarchic nature of International Relations and the primacy of state in international affairs (Gilpin 2001). The difference of Gilpin with other Realist scholars such as E.H. Carr and Morgenthau is that Gilpin acknowledged the presence of corporation, civil society and norms. Gilpin defined IPE as the interaction of market, state, international organization, multinational corporation and other powerful actor. However, Gilpin directly answered the hierarchy of these actors by mentioning states as the primary institutions that able to set the rules and influence the outcome.

This article disagree with Gilpin's primacy of state. IPE is considered as an arena for power struggle and states are the holder of military power, diplomacy and foreign policy, bureaucrats and experts as well as natural resources, those component that outsmart other actor in IPE. English School considered IPE as a changing and dynamic arena that allows transformation and revolution of the established structure. The presence of new norms such as human rights and environmentalism and new actor such multinational corporation and civil society can transform the aggressiveness of state and its national interests that make the inherent nature of power political rivalry become debatable.

By taking English School as an IPE perspective, we can see on how government gives multinational corporation legitimate role in official multilateral negotiations. Due to the lack of funding, government relied on corporation in terms of foreign direct investment. Global companies such as Microsoft, Google, Samsung, Toyota or British Petroleum has bigger role in national political system because they are able to operate their production in two or more countries with significant level of financial, component, and operational flows. Interestingly the flows between different segments and different countries of the corporation is greater than the flows within a particular country. Corporation has significant economic and social effects at a global level as their incomes are much bigger than the states. 
IPE become a place for complexity as multinational corporation brings harm to the environment and the poor. It is known for the phenomena of racing to the bottom. It is said that corporation has geographical flexibility that is an ability to shift resources and operations between different locations on a global scale. They wanted to invest in less developed countries to exploit their natural and labor resources and traded for manufactured goods from the developed countries. The Anganwadi workers in India are paid only $\$ 21$ a month and their helpers $\$ 11$ (Balaam and Dillman 2011, 566). There is no allowance, no paid leave, and they also do not have social security. The corporation exploitative behaviour and pure profit-oriented mechanism are resulted to the loss of the poor and it provoked protests and resistance from civil society. Greenpeace and many international non-governmental organization have successfully lobbied for embargo to stop the consumption of the products from the exploitative corporation. The success of Greenpeace has generated a complexity of IPE which hardly understood from realism perspective. It is even more confusing for realists to understand government's decision to comply World Trade Organization's international law and European Union. In the case of banana wars, for example, the EU can find its solution to its rivalry with the United States through complying the ruling of dispute settlement mechanism of World Trade Organization. The notion of international law and international court become feasible and open for discussions.

\section{International Law}

As the century turned, governments and individuals faced the following international legal actions due to their potentially harmful economic foreign policies. There has been so many cases that governments brings their trade-related case to dispute settlement body of World Trade Organizations such as banana wars, Boeing vs Airbus, or dumping-related policies. Even great powers turned to international law as the solution for their conflict. International law is IPE's primary institutions.

As a primary function, we need to know its source of law, function, and the process of turning to law. According to Article 38 International Court of Justice (ICJ), there are four source of international law namely international agreement, customary law, general principles of law, and the opinion of expert (Besson 2010, 164).

Yasuaki (2003, 106-109) mentioned that there are three function of international law. Firstly, law is used as communication media. Nation exist as sovereign states. They must thus coordinate and accommodate mutually conflicting interests and seek to coexist peacefully and to prosper in international society where common interests and norms are scarce. Consequently, they negotiate with each other in order to maximize their own interests under various conditions and restraints. Even when they are engaged in war, they need to communicate with each other because they need to know a wide range of things; what kind of counterattacks they would invite by their own attacks; how the other party would respond if they abuse prisoners of war and civilians of the other party; under what conditions the other party would be willing to make a truce and/or peace, and so on. International law provides a common language and framework of exchange of claims in the argumentative process between states.

By resorting to international law, a nation can send a message to the other party that it is ready to settle an issue via the standard and the framework which is common to them, rigid in nature, associated with justice and fairness, binding not only on the other party but also on itself, and enforceable as the last resort. In this way, international law provides an important instrument to mediate conflicting parties. International law provides a common language for the communication of members in international society. 
Secondly, international law is embodying shared understanding of international society. International law is to embody and express shared ideas and understandings of the constitutional structure and legitimate aspirations of international society to its diverse members. By this function, international law indicates common positive rules of behaviour and induces convergence of behaviours of diverse international members, thereby contributing to the smooth management of international relations and to the realization of common ideas and aspirations of international society.

Thirdly, international law is used as the tool of justifying and legitimating function. Every state justifies international behavior of its own and seeks to deny the legitimacy of the behaviour of opposing states. Even realist international relations scholars or deniers of the relevance of international law tend to admit that states use international law as an instrument of justification. Or, they argue that the only meaningful role of international law is to justify the policy of states, especially to justify the policy of maintaining the status quo.

To understand the implementation of international law in international political economy, we can use the concept of legalization developed by Robert Keohane, Kenneth Abbot, Andrew Moravscik, Anne-Marie Slaughter and Duncan Snidal. Legalization refers to the process of creating legal instruments based on diplomatic process and government interaction. According to Keohane, Abbot, Moravscik, Slaughter and Snidal, there are three dimension of legalization that is obligation, precision, and delegation. This article would draw the new structure of international law inspired by the three dimension of legalization.

Obligation in the legalization of Keohane means that the compliance of states or other actors to a set of rules. It refers to the commitment of states to uphold the law despite of its contradicting interest. In the context of national domestic system, obligation can be seen on the constitution, law and rules which elaborated the specific of the prohibited act and the positive act. Precision refers to the certainty on the interpretation and the sustainability of the rules. The ideal type of certainty will not give any ambiguity and confusion regarding the rules. Delegation refers to the possibility of punishment for any violation of the rules. There will be third parties that assigned to give the punishment or further rules.

As elaborated in the figure 1 , the obligation would prefer the process of change from expressly non-legal norm to binding rules. Meanwhile, precision would change the situation of confusion and ambiguity to precisely and highly elaborated rules. Lastly, in the delegation, the situation of anti-punishment of diplomacy should be transferred to the possibility of punishment by international court.

Figure 1. The Dimensions of Legalization

Obligation

Precision

Delegation

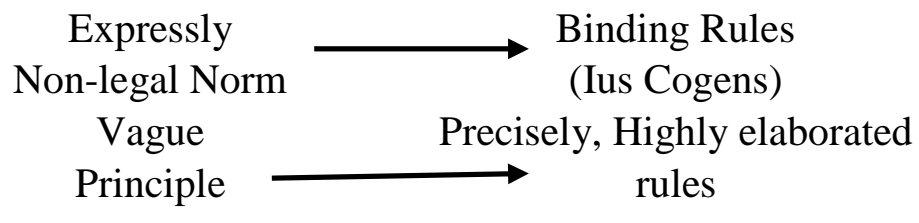

Diplomacy $\longrightarrow$ International court,

Source: (Abbot, et al. 2006, 119)

\section{South China Sea Dispute and Permanent Court of Arbitration (PCA) ruling}


After the Permanent Court of Arbitration issues its verdict, China immediately denounced the PCA ruling as "null and void" with "no binding effect on China," and accused the PCA of having "abused relevant procedures and severely violated the legitimate rights that China enjoys as a State Party to the UNCLOS" and "eroded the integrity and authority of the UNCLOS" (Cohen 2014, 21). It labelled the Philippines' initiation of the arbitration "a political provocation under the cloak of law" and again called on the Philippines to resolve its disputes with China "through negotiations and consultations (Cohen 2014, 21).

International law is facing a crisis of legitimacy due to non-compliance of China. The rise of China as a new economic superpower brings implication to their foreign policy. It is assumed that international law is considered as a tool for superpower to obtain their national interests but in the case of South China Sea dispute, international law is seen as inferior to diplomacy and power political calculation.

In the past, China didn't show its aggressiveness and prefer to put sensitive and potentially conflictual issue under the heading of economic cooperation. On his visit to Beijing, The Philippines Vice President Salvador Laurel told the media that "the South China Sea issue can be put aside at the moment. We will not allow this issue to hamper [our] friendly relations with the Philippines and other countries (Cohen 2014, 24).

However, China's decision to build artificial islands in the Scarborough Shoal and Paracel Islands has provoked the protests and anger from neighbors. China has spent trillion of dollars to build those islands with full military advance support and facilities. The artificial islands are also located on the global network of trade that potentially harmed the global trade through South China Sea. We can see the behaviour transformation of China that was developing countries turned into a new economic great power.

As stated in the previous sub-chapter, China has the option to use international law to send the message to other claimants states that they are ready to settle an issue via common standard and framework. By having the decision of the court, China have higher legitimacy of South China Sea and justification to exploit the natural resources of South China Sea. China missed this opportunities when they build the artificial islands and instead used military power to enforce its claim on South China Sea.

We learned that Hedley Bull's claim of international law was valid. Bull said that the effectiveness of international law depends on the balance of power. The power gap is a threat to balance of power and each state in the world has to decrease its power gap with neighbors and other states. The increasing power gap will bring balance of power and international law ineffective. The presence of hegemon disrupts the implementation of international law. In the case of South China dispute, international law is considered as important in the phase of existing of balance of power between China and the claimants states and turned to imbalanced as China gained its status as economic great power. The only way to re-enforce international law in IPE is to bring China's rival that is the United States as the other great power.

44th United States President Barack Obama used the PCA ruling to criticize the aggressiveness of China in South China Sea. However, Obama didn't further moved to enforce the law; only limited to condemnation and diplomatic note. This is giving greater opportunities for China to continue its claim on the sea and strengthening its military power on the artificial islands. The balance of power is still not appeared in the conflict with international law considered as paper tiger. This situation is changing after the newly-elected United States President Donald Trump that enforced the law with the additional military instruments in the conflicts.

From the case of South China Sea dispute, it can be concluded that the crisis of international law in the IPE is mainly due to the lack of enforcement. There is a constant debate on the enforcement of international law. Pluralists believed that there must be consent, approval and support from states to enforce the law. Sovereignty is still the heart and blood of international 
society and international law must follow from it. However, the solidarists believed that there must strict enforcement of international law by creating higher authority with the capability and capacity in terms of military, economic and diplomacy to impose punishment to the states.

In the case of European Union, European Court of Justice has its legal and political legitimacy to impose sanctions to the members of European Union. World Trade Organizations has also the capacity and capability to impose sanctions. Solidarists believed that the absence of this higher authority will cause chaos and war.

Meanwhile, pluralists refers to ASEAN in solving disputes peacefully without resorting to international law. In the case of human rights abuse in Myanmar, European governments and United States protested the military junta due to their lack of respect to democracy and human rights values. There were many reports of prisoner tortures, political prisoners, forced migration and genocide toward minority groups. However, ASEAN prefers to settle the conflict through diplomacy and personal contacts. The activists condemned the ASEAN way as it takes long time and not transparent to the media. Myanmar finally implemented its democratic election and released all the political prisoners.

The effectiveness of international law is very important in determining whether international law can be considered as primary institution of international society and whether war, great power politics and diplomacy can be considered as secondary institution. The effectiveness of international law is very important in determining whether international law can be considered as primary institution of international society and which institutions that can be considered as secondary institution of international law.

Basak Cali (2010) mentioned that there is a possibility of full overlapping between international law and International Relations. Diplomacy, great power politics and war can be also studied with international law. The problem is the criteria or justification for including diplomacy, great power politics or war into international law. Hedley Bull and other English School scholars treated international law and International Relations as separate primary institution.

Despite the full implementation of PCA ruling on South China Sea, international law itself can be modified according to the reality and the empirical data. International law is not only a normative enterprise but also a conceptual and empirical knowledge that enable researchers "to identify the relevant concepts for inquiry as well as hierarchy, categorization, and relationship between different concepts" (Cali 2010, 12).

South China Sea dispute shows that the normative dimension of international law is failed. The eagerness of international lawyer to impose sanctions to states met resistances from state leaders that they looked for solutions that gave win-win solution especially to great powers. China were not satisfied with the Philippines's legal approach as it is a win-lose scenario in which China can be the victim of the scenario. Therefore, China welcomed the newly-elected Philippines President Rodrigo Duterte that focused to economic and business diplomacy as it will appease the negative impact of the rivalry of South China Sea. In his visit to Beijing in October 2016, Duterte brought more than 200 business leaders to invite Chinese investment to Manila in terms of infrastructure, trade facilities, and socio-cultural cooperation.

Economic diplomacy is the terms of international law. If we want to have China works on the international law of South China Sea, the secondary institution would be economic diplomacy. China is the second biggest trading partner for the Philippines after Japan. China is the biggest source of imports and went up 26\% from 2015 to 2016 (Shead 2017). Chinese tourists were eager to go to Manila shown from the numbers of Chinese tourists that has increased significantly.

Duterte's decision to change the pace of the international into economic diplomacy resulted to concrete projects between Manila and Beijing. In his visit to Beijing, Duterte was successful to secure US\$24 billion of investment and loan to be distributed in the infrastructure and energy 
sector. If this economic diplomacy can be enforced as the secondary institution of international law then South China Sea dispute can be solved through joint management of exploration and sea border control by China and the Philippines.

The idea of economic cooperation can be adopted to joint management control of South China Sea. In economic cooperation, there are two values to be respected, non-discrimination and anti-protectionism. In WTO, states are prohibited to discriminate certain products and services from certain country and applied the spirit of free competition. In South China Sea, non-discrimination and anti-protectionism would be translated into transparency and multistakeholder dialogue. International law of South China Sea would be determined by the degree of engagement with transparency and inclusiveness.

Figure 2. The Structure of International Law as Primary Institution

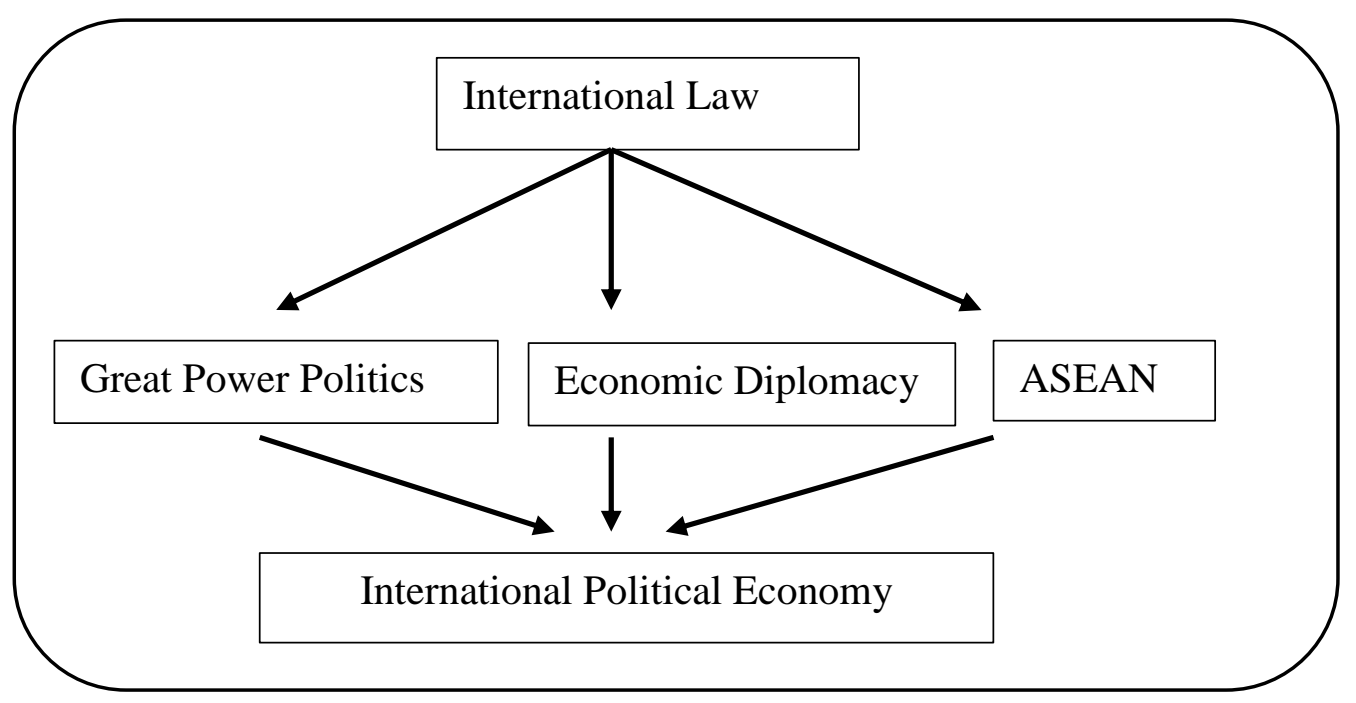

The second secondary institution of international law of South China Sea would great power politics. Hedley Bull defined the great power politics as the primary institution of international society. However, this article argued that putting great power politics as the primary institution and international law as the secondary institution are indicating the aggressiveness behaviour of China. This article argued that aggressive China would be irrelevant in the context of South China Sea as there were many measures showing humanitarian cooperation and joint economic cooperation between China and the neighbors.

Adam Nieves Johnson also argued that China can be seen as the humble-hard power that used nonmilitary means in settling the disputes of South China Sea. Johnson further argues that humble-hard power is neither threatening militarily nor is it peacefully diplomatic, and exerting this form of power can achieve goals without creating international headlines and condemnation (Johnson 2012, 45). Great power politics can be compatible with international law if the nature of the relationship would be less offensive.

Bull (1977) have elaborated the role of great power and mentioned six functions of great powers namely (1) preservation of general balance, (2) avoidance of crisis, (3) limitation of war, (4) the unilateral exercise of local preponderance, (5) spheres of influence, interests and responsibility, and (6) a great power concert. This article will elaborate on the first and the fifth function of great power. Bull stated that "general balance is one in which the great powers are 
the principal ingredients, and that actions taken to preserve it depend principally on measures of contrivance, including measures of collaboration, among the great powers" (Bull, 1977, 201).

In the context of South China Sea, China willingness to intensify cooperation with the neighbors is an example of contrivance. It is also important on the relationship between China and the United States on the South China Sea dispute. The interaction between China and the United States will determine the effectiveness of international of South China Sea. It doesn't mean that international law become vague, but international law should give greater opportunities for great power to modify and adapt to international law.

The problem with the contemporary international law of South China Sea is that China is not treated as the great powers. The failure of PCA ruling is that it was taking for granted the supremacy of international court neglecting the role of China as a great power. The lack of engagement between the court and China was the embrio of the failure of PCA ruling. PCA ruling is considered as an attack to the sovereignty of China and the response is the denial of international law itself. This will be related to the fifth role of great powers. There should be greater sphere of influence, interests and responsibility for China.

The last part of international law of South China Sea is ASEAN. As an international organization, ASEAN has performed its role as forum and instrument. ASEAN has done many meetings regarding South China Sea and has signed the Declaration of Conduct in 2002. Many scholars have criticized the ineffectiveness of ASEAN in finalizing the binding Code of Conduct on South China Sea due to inherent internal dispute. South China Sea dispute has divided ASEAN into three clubs; pro-China (Indo-China states), pro-UNCLOS (Vietnam, the Philippines) and non-bloc (Indonesia and Singapore). The deadlocked of Code of Conduct has been dramatized as the failure of ASEAN and international law of South China Sea.

This article argued that ASEAN should not be treated as an independent actor. As an independent actor, ASEAN, like the European Union, can propose and guide the negotiation process into certain outcome and has the power to impose rule on the member states. This is not compatible with the configuration of great power politics and economic diplomacy within the international law of South China Sea as shown by the failure of Code of Conduct and PCA ruling.

The role of ASEAN should be limited to forum and instrument for its member states combined with role of China as the great power. ASEAN has its own ASEAN Way that prefers consensus, personal communication and musyawarah mufakat as the way for solving dispute (Acharya 2001). It is also important to emphasize the protection of sovereignty of states in ASEAN. The state-centric paradigm of ASEAN has been a factor for Chinese interest in ASEAN.

\section{Conclusion and Recommendation}

The failure of PCA ruling is seen as the crisis of international law in the international political economy. China intentionally neglect the legitimacy of PCA ruling and continue its reclamation project in the Scarborough Shoal and Paracel Islands. This article argues that we need change the conception of international law by taking out the normative dimension of international law. International law should not be seen as a grand project of transformation of state-centric International Relations to national domestic politics alike with higher authority with the capability and capacity in terms of military, economic and diplomacy to impose punishment to individuals.

This article uses English School as the theoretical framework with pluralism and solidarism as the conceptual component. The pluralism has shown that sovereignty is still the heart and the blood of International Relations meanwhile the solidarism believed that international law would be effective with the capacity and capability to impose punishments to member states. 
The South China Sea dispute reflected the debate between pluralism and solidarism and the debate has helped this article to construct international law as the primary institution with great power politics, economic diplomacy and ASEAN as the secondary institution.

The pluralism version of South China Sea is obvious when the PCA decision has been used by the Philippines to be bargaining tool to obtain economic cooperation and appeased the failure of PCA ruling. The PCA decision also has provided momentum for China to transform their policy related to the South China Sea dispute with its role as the great power. 


\section{REFERENCES}

\section{Books}

Abbot, Kenneth, Robert Keohane, Andrew Moravscik, Anne-Marie Slaughter, and Duncan Snidal. 2006. "The Concept of Legalization." In International Law and International Relations, by Beth Simmons and Richard Steinberg, 115-131. Cambridge: Cambridge University Press.

Acharya, Amitav. 2001. Constructing a Security Community in Southeast Asia: the Problem of Regional Order. London: Routledge.

Balaam, David N., and Bradford Dillman. 2011. Introduction to International Political Economy. Boston: Pearson.

Besson, Samatha. 2010. "Theorizing the Sources of International Law." In The Philosophy of International Law, by Samantha Besson and John Tasioulas, 163-187. Oxford: Oxford University Press.

Bull, Hedley. 1977. The Anarchical Society: A Study of Order in World Politics. Basingstoke: Palgrave.

Buzan, Barry. 2004. From International to World Society: English School Theory and the Social Structure of Globalisation. Cambridge: Cambridge University Press.

Cohen, Jerome. 2014. "International Arbitration and Adjudication as South China Sea Confidence-Building Measures." In Perspectives on the South China Sea: Diplomatic, Legal and Security Dimensions of the Dispute, by Murray Hiebert, Phuong Nguyen and Gregory Poling, 20-24. Boulder: Rowman \& Littlefied.

Gilpin, Robert. 2001. Global Political Economy: Understanding International Economic Order. Princeton: Princeton University Press.

Hayton, Bill. 2014. The South China Sea: The Struggle for Power in Asia. New Haven: Yale University Press.

Johnson, Adam Nieves. 2012. A Bilateral Analysis of the South China Sea Dispute: China, the Philippines, and the Scarborough Shoa. Miami: Florida International University.

Thanh-Dam Truong, and Karim Knio. 2016. The South China Sea and Asian Regionalism A Critical Realist Perspective. Springer: Mosbach.

\section{Journal}

Yasuaki, Onuma. 2003. "International Law in and with International Politics: The Functions of International Law in International Society." European Journal of International Law 105-139.

\section{Website}

Shead, Bob. 2017. The Philippines' Economic and Political Relations With China. April 10. Accessed July 12, 2017. http://www.aseanbriefing.com/news/2017/04/10/philippineseconomic-political-relations-china.html. 